\title{
Library Considerations for the Colonial Impacts of Indigenous Cookbook Publishing
}

\section{Devon Stolz ${ }^{1}$}

\author{
${ }^{1}$ Master of Library and Information Studies (MLIS), University of Alberta, Email: \\ stolz@ualberta.ca
}

To Cite:

Stolz, D. (2021). Library consideration for the colonial impacts on indigenous cookbook publishing. Pathfinder: A Canadian Journal for Information Science Students and Early Career Professionals, 2(2), 35-52.

https://doi.org/10.29173/pathfinder29

\begin{abstract}
According to Natifs (North American Traditional Indigenous Food Systems), the first action in understanding the Foundations of an Indigenous Food System Model is the "Removal of Colonized Thought." Food sovereignty, physical and spiritual connection to Land, and sustainable food practices are interlocked with decolonial action. Considering Traditional Knowledge (TK) as intellectual property, what does it mean for libraries to collect books containing TK, such as cookbooks written by Indigenous authors, published by Indigenous publishers or otherwise dealing with Indigenous Food Systems? Mindful of the colonial impacts on cookbook publishing in Canada, the author proposes a 4-part framework for libraries when acquiring or weeding Indigenous cookbooks to and from their collections. Used as a tool, the framework promotes the stewardship of collections and metadata that do not perpetuate colonial violence through language and Eurocentrism, but champion Indigenous authors, publishers, and content. Written from the position of queer-settler, the essay provides examples of published works that meet the criteria of the framework, celebrating Indigenous Food Systems that predate librarianship's colonial classification. Through personal narrative, the author demonstrates how libraries can integrate the offerings of such texts can be integrated into a personal stewardship of the teachings being shared that directly informs the case for equitable collections management.
\end{abstract}

Keywords: Indigenous cookbooks, Indigenous cookbook publishing, Indigenous publishing, Library considerations, Traditional Knowledge, Canadian Cookbooks

he month of July has always held a special and intoxicating power over my life.
July, the month of my birth - is also the month of long days spent tending plants in the garden, late nights sharing stories around a fire and, most importantly, time spent picking saskatoon berries near the creek behind my family acreage. When I reflect on my childhood spent in the southern part of what is now known as Saskatchewan, these midsummer berries feature prominently. My mom, sister and I would spend days along 
the lazily flowing creek behind our old farmhouse filling pails of saskatoon berries to be baked, frozen and shared with our family who could not afford to spend their July days amongst the berry bushes. Although I did not know it, we were participating in a tradition and way of being that extended far beyond my perception of time and place; a tradition that connected us to traditional ways of life that I can never truly understand. My mother would remind my sister and I not to take all of the berries off of a single bush to be sure that we left some for the animals that lived in these woods. As a child, I unknowingly participated in the gift economy (Wall Kimmerer, 2013) by partaking in a reciprocal relationship with the Land that held an expectation that we would receive the gift of the berries to pass forward while also being mindful that we would eventually give back through learned stewardship towards the forest. Perhaps my mother did not realize that she was passing along teachings that extended beyond herself and into time immemorial. At the time, we were simply picking berries.

Growing up on a homestead near both forest and river shaped my relationship to the Land from a young age and fostered a lifelong interest in healthy, sustainable, homegrown foods. My dad and sister hunted deer each fall and fished from the boat in the summer and through holes in the ice in the winter. My mom and I would tend the garden and ferment our produce, turning garden tomatoes into salsa, beans and carrots into pickles and berries into jams and preserves. My relationship to food has always been personal because I knew the plants and animals that nourished my body and mind. This relationship to food has helped me to cultivate a keen interest in food sovereignty, and sustainable food-ways has allowed me to think about food beyond just what is on our plates.

As a lover of books and learning, I am also drawn to writing about food and particularly cooking and fermentation. I devote a cupboard in my kitchen solely to the storage of cookbooks. And so, as I exist between the world of the kitchen and the study, I find myself thinking critically about the quality and types of cookbooks that are being published as well as the historical implications of cookbook publishing. As both a preservice librarian and established home-cook, I am critical of cookbooks that are purchased and kept within the collection of libraries for reasons that will become clear throughout this essay. I am curious about the context of Indigenous food systems and 
the colonial impacts on Indigenous publishing regarding the writings of food preparation and cultural understandings. I look to understand the implications of the settler colonial project and propose a framework for libraries to use when weeding collections or considering the purchase of new cookbooks written by and for Indigenous communities.

It is imperative that I stress that I am not an Indigenous scholar and that I am writing about cultures of which I am not a part. Both sides of my family are participants in settler-colonialism from the country of Germany and so I do not hold any Indigenous identity. I have lived the majority of my life in the section of Land now known as Treaty 4 which is the territory of the Nêhiyawak, Anishšināpēk, Dakota, Lakota, Nakoda, and the homeland of the Métis/Michif Nation. This paper is being written in oskana kâ-asatêki, now commonly known as Regina, Saskatchewan (University of Regina, n.d.). I have also lived in Vancouver, British Columbia, which is the traditional unceded territory of the Coast Salish Peoples and includes traditional homelands of the Musqueam, Squamish and Tsleil-Waututh Nations (UBC, 2017), and have lived abroad in Northern Japan in the traditional homeland of the Ainu peoples of Aomori prefecture. My education from elementary through to graduate level study has been provided by the colonial institution of Canadian public schooling in which I have also participated as an English, social studies and learning resource teacher. To further situate myself, I hold queer identity that shapes my perceptions of both our constructed and natural world.

This research paper is focused primarily on Indigenous food contexts and publishing but is limited by the scope of language that I employ. "Indigenous" is a term that is being used to denote Indigeneity to the multiple groups of peoples that first inhabited the land now known as North America (Chartrand \& Cockrall-King, 2019). The term is inclusive of Inuk, Métis and First Nations peoples and is being used accordingly throughout my writing. Where possible, I have indicated which specific Nation or group of Peoples that I am writing about. However, due to the colonial past and present, this is not always possible and so at times "Indigenous" is being used in a pan-Indigenous context. I am also limited by the lasting impacts of attempted assimilation and systematic erasure of Indigenous identity from publishing. This has resulted in few primary sources of historic Indigenous cookbook publishing. For the purpose of this paper the term "Indigenous cookbook" is used as a descriptive tool for any cookbook 
that is published by Indigenous Peoples or is about Indigenous Peoples food traditions, cooking techniques and Traditional Food Based Knowledges.

\section{Creating Context}

Food is political. This is something that is undeniable when considering the complexities of food-systems and production. Indigenous food-ways, food sovereignty, security and food-based Traditional Knowledges are imperative to understanding contemporary and historic Indigenous cookbook publishing. This section looks to provide important context towards understandings of Indigenous Ways of Being and Knowing towards food. It is crucial to stress that food sovereignty is at the core of Indigenous cooking and therefore equally at the core of Indigenous cookbook creation and publishing.

The foundations of food sovereignty are rooted upon the rights and equity of culturally appropriate food production through methods that are both ecologically sound and sustainable (Via Campesina, 2007). Indigenous perspectives on food sovereignty focus special attention towards relationships between peoples, ancestors, living things and the Land with a central focus aimed towards the well-being of every participant involved (Coté, 2016). Food sovereignty is directly connected to self-determination and the processes of decolonization:

"[it requires a collective movement toward focusing on] cultural responsibilities and relationships that Indigenous peoples have with their environment. It also requires examining the effort being made by Indigenous communities to restore these relationships through revitalization of their Indigenous foods and ecological knowledge systems as they assert control over their own well-being". (Coté, 2016, p.2)

Food sovereignty is about more than knowing where your food is coming from; it is about creating a relationship to the food that nourishes both body and mind.

Traditional food practices connect closely with Indigenous food sovereignty and have been proposed as a possible solution to food insecurity that impacts Indigenous communities (Elliot, Jayatilaka, Brown, Varley, \& Corbett, 2012 as cited in Muller, 2018). The North American Traditional Indigenous Food Systems organization created by The Sioux Chef (Sherman \& Dooley, 2017) has created a pan-Indigenous model that 
demonstrates the foundations of Indigenous food systems that can be built upon to develop revitalization of traditional food practices.

\section{FOUNDATIONS OF AN INDIGENOUS FOOD SYSTEM MODEL}

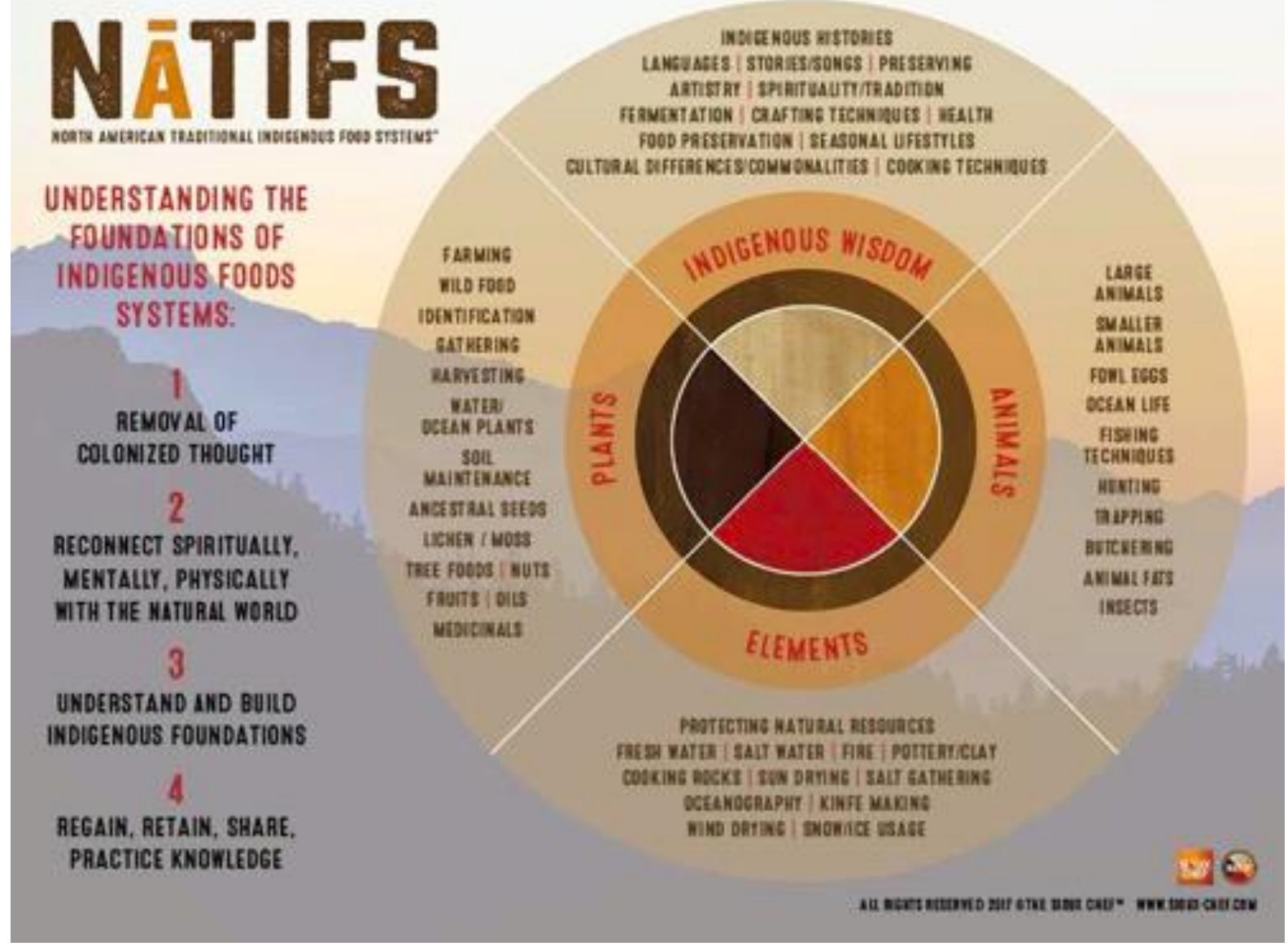

Figure 1. Natifs. (2017). Foundations of an Indigenous Food System Model [Digital Image]. (Sherman, 2017, pp.5).

As shown in Figure 1. the Foundations of Indigenous Food Systems Model (Sherman, 2017) presents the primary understandings of Indigenous food practices which connect the teachings of the Medicine Wheel with Plants, Elements, Animals and Indigenous Wisdom through the middle circle of the diagram. The Indigenous Wisdom section of this model is of particular interest when considering cookbook publishing. "Food preservation, fermentation and cooking techniques" are all identified as part of the Indigenous Wisdom by the North American Traditional Indigenous Food Systems (Natifs, 2017). Indigenous Wisdoms could also be synonymous with Traditional Knowledges (TK), which then creates questions of intellectual property and ownership 
of Indigenous Knowledge publication. Traditional Knowledges are understood to be knowledge frameworks that incorporate skills, modes of learning and unique practices that are cultivated through experience-based learning and are morally imbued and rooted within the idea of place (Cruikshank, 2005; Martin-Hill 2003; Muller, 2018, Alfred, 2005; Coulthard, 2014; Dei, Hall, \& Rosenberg, 2000; Menzies \& Butler, 2006). These knowledges encapsulate traditional world-views that should be viewed as a part of the holistic Indigenous identity and systems of thought (Cruikshank, 2005; Kovach, 2009). The World Intellectual Property Organization (WIPO) Traditional Knowledge Toolkit suggests critical documentation and cautious management of TK as intellectual property (WIPO, 2017). The reframing of recipes and cooking techniques as TK challenges the notion that libraries should be collecting Indigenous cookbooks for use outside of Indigenous communities. However, the documentation of TK allows Indigenous peoples to assert their intellectual property rights and guarantee the maintenance of TK over time by supporting the sharing and dissemination of cultural practices that benefit Indigenous communities (WIPO, 2017). However, authors, publishers and librarians who are involved in the information lifecycle of books that contain Indigenous TK must exercise caution.

\section{Methods and Literature Review}

The methodology of researching this topic involved searching for relevant articles in major databases and repositories such as Google Scholar, JSTOR, Library and Information Science Source, and Academic Search Complete using the queries "Indigenous cookbooks or Indigenous cookbook publishing" and other variations of this phrasing. My intention in gathering academic articles that focus on the landscape of Indigenous cookbook publishing and the impact of colonization was to conduct a systematic literature review to inform my understanding of this specific topic. The majority of results returned were recently published Indigenous focused cookbooks such as tawâw: progressive Indigenous cuisine by Shane Chartrand \& Jennifer Cockrall-King (2019), articles that focus on language revitalization through publishing, or Indigenous children's book publishing, and so were not deemed relevant for my purposes. 
Scholars have done some interesting writing about the topic of Indigenous cookbooks from the nation now known as Australia such as Fredericks and Anderson. Their paper, "We eat more than kangaroo tail or dugong you know...: Recent Indigenous Australian Cookbooks" (2013), explores the Australian landscape of Indigenous cookbook publishing and the impacts of the Australian colonial context and the focus on nutrition within those cookbooks. While the paper is similar in topic to my research, it is limited in its scope as only exploring cookbooks published within the last five year and does not fully explore the effects of colonization on these cookbooks. The publication of academic papers regarding cookbooks that explore Indigenous cultural practices around food and recipes seems to be a niche of academia that has seemingly gone unstudied by North American library and information academics.

\section{Colonial Impacts on Indigenous Cookbooks}

Carrying forward the framing of Indigenous food preparation as TK allows for critical consideration of how the colonial state of Canada has benefited from the appropriation of these Knowledges while failing to give credit or recognition in early published cookbooks and recipe guides. Furthermore, the current Canadian Copyright Act systematically fails and has always failed to protect Indigenous Knowledge from detrimental research, appropriation and harmful theft of Indigenous intellectual property (Canadian Federation of Library Associations, n.d.a). Settler colonialism has resulted in an ongoing legacy of writings about Indigenous Peoples living in the constructed country of Canada that are both limited in quality representation and harmful in stereotypical clichés (The First Nations Information Governance Centre, 2019). The continual attempts at assimilation result in the endemic Indigenous cultural erasure that permeates the cookbooks that populate the Canadian publishing landscape and dominate our bookshelves.

Historically, European explorers and colonizers relied on Indigenous Knowledge to aid in food acquisition and preservation for their survival in the harsh arctic and subarctic climates of their exploration (Duncan, 2006). Pemmican (Creepimikan), the concentrated mixture of dried meats, berries and tallow, became vital for Europeans who ultimately actively destroy the very food systems that their colonization was built upon (Merriam, 1955; The Canadian Encyclopedia, 2015). Later, government informed 
policies such as the Indian Act of 1876 removed Indigenous peoples from traditional homelands and displaced communities onto reserve Lands or into suburban and urban settings that severely damaged the intrinsically Land Based Indigenous food security and sovereignty. Indigenous food-ways were replaced with supermarket chains and commodity rations that provided low nutritional value (Hall, 1994). These oppressive government policies, lacking in understanding and empathy towards TK, compromised Land Based teachings and severely hindered intergenerational learning around traditional food practices. Furthermore, the residential school system, as created by the Canadian department of Indian affairs and administered by Christian churches, actively worked to assimilate and remove Indigenous children from their homes, culture and consequently Indigenous ways of being and knowing. The 1906 text Teaching the rudiments of cooking in the classroom-Primary Methods and Outlines for the Use of Teachers In The Indian Schools by the American Department of the Interior, Office of Indian Affairs, crudely outline the home-economic education that students received while attending American Residential Schools. The book operates under the assumption that students know nothing about how to prepare and cultivate food and denotes considerable amounts of time to be spent teaching students English food vocabulary and how to properly set a table. Lesson XIV is titled "Uses of stale bread" and simply states "bread pudding" which is demonstrative of the lack of effort put into developing this curriculum (Department of the Interior, 1906, p. 59).

The colonized thought processes which permeate this curriculum guide and other texts of the era is demonstrative of the myriad of ways in which residential schools failed students and weaponized the lack of education to considerable consequence. The Potlatch Law of 1880 banned through oppressive force the practice of Indigenous cultural ceremonies by making participation punishable as a criminal offence (Indigenous Corporate Training, 2012). The Potlatch, which is an important facet of coastal First Nations life and Indigenous identity in the geographic area now known as British Columbia, involves shared feasts, dance and speeches (Indigenous Corporate Training, 2012). The ban, which was removed from the Indian Act in 1951, is indicative of the systemic colonial oppression that actively worked to commit cultural genocide. Generations of coastal Indigenous peoples have been deprived of years of food-based 
tradition, knowledge and teachings. The colonial effects of the generations-long Potlatch ban on Indigenous food-ways would also later impact Indigenous food

publishing. To write about Indigenous publishing without mention of the Canadian colonial project and its detriment would be a disservice to the knowledge which has been lost due to the oppressive policies of colonial governments.

\section{The Publication of "Canadian" Cookbooks}

Early cookbook publishing in Canada is notoriously difficult to chronicle due to the majority of cookbooks existing outside of the typical publishing sphere (Driver, 2008). These books were collections of recipes as written by community groups or food manufacturers instead of conventional authors and publishers. Prior to the formation of the National Library of Canada in 1953, no institution was creating a comprehensive collection of Canadian cookbooks (Driver, 2008 \& Scott, M., \& Sylvestre, G., \& Snyder, L., National Library of Canada, 2013). This early Canadian food writing and publishing landscape had an ethnocentric focus on European influenced cuisine from confederation until the mid 20th century. As Cooke (2009) explains in her book titled What's to eat? Entrées in Canadian food history, most published early Canadian cookbooks explicitly used the word "Canadian" in the title, which worked to achieve a kind of unification of "Canadian" identity; this is much like the American idea of a "melting pot" where identities and cultures merge to create a consolidated national identity.

These early cookbooks can be divided into five periods: contact and settlement, consolidation, affiliation, articulation and differentiation (Cooke, 2009, p. 4,5). Early Canadian cookbooks such as The Female Emigrant's Guide (1854), La cuisinière canadienne (1840) and Canadian Housewife's Manual of Cookery (1861) act as settlement and consolidation cookbooks, which were published for settler women to cook in a Canadian context while also dictating what that context should taste like. The consolidation phase resulted in books that compiled information from other colonial books about cookery (Cooke, 2009). Cooke connects affiliation and articulation cookbooks to institutions that worked to achieve a constructed homogeneous Canadian identity. Examples of these books include Canadian Cook Book (1923), Manuel de 
cuisine raisonnée (1919) and Kate Aitken's Canadian Cook Book (1945). It is notable in the context of Indigenous publishing that these cookbooks clearly were not by, for or about Indigenous peoples and foods. The few books written about Indigenous foods at this time were often anthropological, ethnographic or government documents. An example of early Canadian Indigenous food writing is Memoir 86, No. 12, Anthropological Series, Iroquois Foods and Food Preparation (1916) by F.W Waugh on behalf of the Canadian Federal Department of Mines (Waugh, 1916).

The fifth phase (differentiation) of Cooke's five periods was the start of a notable shift in Canadian food publishing. While the hegemonic focus on "Canadiana" as a cultural identity persisted into the 1960's, a noteworthy tide of recognizing increasingly diverse foodways began to populate the collective "Canadian" psyche. The world's fair that was held in Montreal in 1967 (Expo67) is considered to be the catalyst for a period of "intense introspection" for Canadian food writers, cooks and publishers (Cooke, 2009; Meyers, 2011) that continues to the present day. Expo67 presented Canadian cuisine as regionally based with a focus on endemic ingredients to each region. As Canadian society continued to diversify so too did Canadian culinary scholarship, publishing and writing. However, the academic study of Canadian domestic foodways remains a particularly understudied field when compared to food scholarship within the American context (Cooke, 2009). Books from the differentiation period, which ranges from the sixties to present day, have a focus that has shifted away from the nationalistic "Canadiana" identity and towards a more inclusive focus on regionalism, immigrant fusion cuisine and the beginnings of Indigenous voices and representation within Canadian cookbook publishing.

\section{Contemporary Indigenous Cookbooks \& A Framework for Library Acquisition/Weeding}

Canada's continued colonial legacy has proliferated to the present day through negligent policies that fail to protect Indigenous Knowledges and maintain the reductionist and damaging status-quo. However, despite the barriers enacted to damage Indigenous publishing, beautiful, well-crafted cookbooks that are written, 
photographed and published by Indigenous peoples are now sitting on my kitchen counter. Although I do believe that this is something worth celebrating, the books that I was able to borrow from the Regina Public Library are not all beacons of decolonial publishing, nor do they signal a drastic shift in Canadian publishing. These small improvements in Canadian publishing are born out of incremental awakenings to the detrimental consequences of colonial ethnocentrism.

Each Indigenous cookbook in my kitchen varies in the degree to which the language and writing has been decolonized and many books published today lack respect for Indigenous perspectives and cultural protocols (Younging, 2018). Books published in the 1990's and earlier often use pejorative language both in content and cataloging-in-publication data. Books are still being written by non-Indigenous authors or are using pan-Indigenous language that fails to serve individual communities or traditions. However, where there are failures in publishing there are also triumphs. The stunning 2019 book tawâw: Progressive Indigenous cuisine by Shane Chartrand (Enoch Cree Nation) and Jennifer Cockrall-King, published by House of Anansi Press Inc is a beacon of Indigenous cookbook excellence (Chartrand \& Cockrall-King, 2019). The book celebrates Indigenous food sovereignty, Traditional Knowledges and Indigenous ways of knowing/being. The Library and Archives Canada Cataloging in Publication is still questionable, as it lists identifiers as "Canadiana" and subjects as "Cooking, Canadian" and "Native peoples - Food - Canada" (Chartrand \& Cockrall-King, 2019).

However, there has been a push away from hegemonic library classification systems for Indigenous materials and towards more inclusive cataloging language. For example, the Xwi7xwa Library - an Indigenous academic library associated with the University of British Columbia - uses its own classification system to organize materials as well as using the subject heading "First Nations" rather than the library of congress subject heading "Indians of North America" (X Xwi7xwa Library, n.d.). The classification system which was developed by Brain Deer was designed for localized use in Indigenous libraries that reflect the local Indigenous peoples while also connecting to relationships between people, animals and the land (Weihs, 2019). A book that is as carefully crafted and considerate as tawâw deserves equal consideration from the librarians and cataloguers who create the metadata to accompany the book. 
It is crucial that librarians purchasing materials that cover Indigenous cultures and foods for their collections exercise careful consideration. I propose a simple framework for collection development librarians to use when purchasing new cookbooks or when weeding existing library collections. This framework is part of the wider initiative to decolonize libraries by working towards truth and reconciliation which aims to deconstruct the power imbalances and dynamics that continually position Indigenous Knowledges and publications as "less" or "other" than settler colonial/European knowledge and books (Canadian Federation of Library Associations, n.d.b).

The framework that I propose encourages librarians to make careful examinations of the following four categories when adding to or weeding collections that contain Indigenous content. By taking time to review each category before the collection of a new Indigenous cookbook, libraries ensure that they are engaging in culturally appreciative practices that do not further contribute to colonial violence and oppressive trends that perpetuate the library as a colonial institution. The categories are authorship, content and writing, publisher and metadata:

1. Examine authorship: Librarians should examine who has written the work and if the author(s) have expressed Indigenous identity. If Indigenous identity has been expressed, which unique community do they belong to? If the author holds nonIndigenous identity, do they have a history of culturally appreciative and respectful writing? Does the author belong from within the community/culture? Be careful to avoid authors who are writing about an Indigenous community without holding Indigenous community connections.

2. Examine content and writing: It is imperative that the content of the book is culturally responsible and does not appropriate Indigenous Knowledges without credit or appreciation. Look for indications of culturally sensitive and decolonized language such as appropriate capitalization, use of contemporary labels, and group names that do not contain old stereotypes that can be harmful and reductive. Texts that are responsive of Indigenous protocols around Indigenous TK should be favoured over texts that perpetuate the publication of TK without Elder or Community consent. 
3. Examine the publisher: Publishers of Indigenous information should demonstrate a proven history of responsible publishing that promotes while also protecting Indigenous intellectual property rights. Some examples of Canadian Indigenous publishers include but are not limited to Theytus Books, Pemmican Publications, Louis Riel Institute, Kegedonce Press, Gabriel Dumont Institute Publishing and Inhabit Media (UBC, 2020).

4. Examine the Metadata: By ensuring that the subject headings and classification data are culturally sensitive, it ensures that library users will be able to locate the book in a way that is not further damaging to Indigenous library patrons and does not perpetuate systems of oppression. Collections management and cataloguing librarians should exercise caution when encountering a book that uses out-dated or insensitive language in metadata.

These are simple yet important examinations that can be used to determine if the books are worthy of being added to a library collection or if they should be removed from the lending collection. Only through specific, actionable steps can libraries start the process of truly decolonizing the information that is stored and presented to library patrons.

\section{July Feast}

On July 4th 2020 I began my third decade of life. The end of my twenties and start of my thirties seemed like a momentous occasion that required an equally large celebration of food and drink. In reality, I had just been so steeped in researching Indigenous cookbooks that I took the opportunity to plan a menu that was sure to delight my guests. The meal took place on a friend's acreage near the Cypress Hills in the South Western corner of the province now known as Saskatchewan. A small collection of my closest friends were present for the meal of salt roasted beet and goat cheese salad with candied pistachios (tawâw: progressive Indigenous cuisine, Shane Chartrand \& Jennifer Cockrall-King pg. 121), grilled oyster mushrooms and carrots, clam fritters (Where people Feast: An Indigenous Peoples Cookbook, Dolly and Annie Watts, pg. 50 ), cheesy parmesan and thyme polenta (Cooking with the Wolfman: Indigenous Fusion, David Wolfman \& Marlene Finn, pg. 220), rabbit braised with apples and mint, and wojape berry sauce (The Sioux Chef's Indigenous Kitchen, Sean Sherman \& Beth Dooley, pg. 115 \&173) served with iced Labrador tea (tawâw: progressive Indigenous 
cuisine, Shane Chartrand \& Jennifer Cockrall-King pg. 133). This meal was crafted with careful consideration as I strived to use the finest examples of contemporary Indigenous publishing. I wanted the meal to pay respect to the Indigenous Knowledges that I had encountered while researching this paper with a focus on sustainable ingredients that were local to my prairie home (with the exception of the clam fritters- which are delicious and I couldn't help myself). While I took time to choose books that I felt were good representations of Indigenous cookbook publishing, it is imperative that I stress that I am not the one who decides the quality of Indigenous publishing. While I was raised with close proximity and relation to the land and an appreciation of Indigenous culture and food-systems, I also have been a participant in colonial systems of oppression and knowledge privileging. The practice of settler-colonial peoples assigning value to Indigenous publishing is an innately harmful practice that I do not wish to partake in. Likewise, I also do not assign myself the title of "ally" to Indigenous peoples in publishing as I feel like my allyship and advocacy for Indigenous publishing must be approved and given to me by Indigenous peoples, and so it should not be a title that I prescribe upon myself. I encourage settler colonial librarians to exercise caution when engaging in the determination of the quality and value of Indigenous cookbooks.

Indigenous food systems and sovereignty have persisted through the Canadian colonial project and will undoubtedly continue into the future. However, the contemporary resurgence and appreciation of Indigenous language and food ways revitalization will confidently result in the publishing of books that are void of harmful the stereotypes, language and misrepresentation that have been commonplace throughout the history of Canadian publishing. Furthermore, libraries that have taken appropriate action in response to restorative justice have an obligation to champion Indigenous publishing and to remove works from collections that perpetuate colonial violence. New publishers and strong Indigenous voices of chefs, librarians and authors are working to ensure that culturally sensitive and empowered Indigenous cookbooks will be present on our shelves and in our kitchens. This has the power to impact what is on our plates and ultimately, who we are.

\section{Conflict of Interest Statement}

None declared. 


\section{References}

Alfred, T. (2005). Wasa'se: Indigenous pathways of action and freedom. Broadview Press.

Aitken, K. (1945). Kate Aitken's Canadian cook book. WM. Collins Sons \& Co. Ltd.

Canadian Federation of Library Associations. Position statement: Indigenous Knowledge in

Canada's Copyright Act. http://cfla-fcab.ca/wp-content/uploads/2018/05/CFLA-

FCAB Indigenous knowledge statement.pdf

Canadian Federation of Library Associations. (n.d.b) CFLA-FCAB Truth and Reconciliation

Report. https://cfla-fcab.ca/en/indigenous/trc report/

Canadian Housewife's Manual of Cookery. (1861). The Canadian housewife's manual of cookery: carefully compiled from the best English, French \& American works, especially adapted to this country.

https://archive.org/details/cihm 64026/page/n11/mode/2up

Chartrand, S., Cockrall-King, J. (2019). Tawâw : progressive Indigenous cuisine. House of Anansi Press Inc.

Chavette, E. (1884). La conquête d'une cuisiniere. Paris: C. Marpon et E. Flammarion.

Cooke, N. (2009). What's to eat?: entrées in Canadian food history. McGill-Queen's University Press.

Coulthard, G. S. (2014). Red skin, white masks: Rejecting the colonial politics of recognition. University of Minnesota Press.

https://doi.org/10.5749/minnesota/9780816679645.001.0001

Coté, C. (2016). "Indigenizing" food sovereignty. Revitalizing Indigenous food practices and ecological knowledges in Canada and the United States. Humanities, 5(3), 57. https://doi.org/10.3390/h5030057

Cruikshank, J. (2005). Do glaciers listen? Local knowledge, colonial encounters, and social imagination. UBC Press.

Dei, G. J. S., Hall, B. L., \& Rosenberg, D. G. (2000). Introduction. In G. Dei, B. Hall, \& D. Rosenberg (Eds.), Indigenous knowledges in global contexts: Multiple readings of our world (pp. 3-20). University of Toronto Press.

Driver, E. (2008). Culinary landmarks: a bibliography of Canadian cookbooks, 1825-1949. University of Toronto Press. 
Duncan, D. (2006). Canadians at table: food, fellowship, and folklore: a culinary history of Canada. Dundurn Press.

Elliot, B., Jayatilaka, D., Brown, C., Varley, L., \& Corbett, K. K. (2012). "We are not being heard": Aboriginal perspectives on traditional foods access and food security. Journal of Environmental And Public Health, 2012(9). https://doi.org/10.1155/2012/130945

The First Nations Information Governance Centre. (2019). First Nations data sovereignty in Canada. Statistical Journal of the IAOS, 2019(35), 47-69. DOI: 10.3233/SJI-18

Foster, J., Pemmican (2015). In The Canadian Encyclopedia. https://www.thecanadianencyclopedia.ca/en/article/pemmican

Fredericks, B., \& Anderson, M. (2013). "We eat more than kangaroo tail or dugong you know...": Recent Indigenous Australian Cookbooks. M/C Journal, 16(3). https://doi.org/10.5204/mcj.648

Hall, S. (1994). Urban social movements, 'race' and community. In P. Williams \& L. Chrisman (Eds.), Colonial discourse and post-colonial theory: a reader. Columbia University Press.

Indigenous Corporate Training. (2012, October 16). Potlatch ban: Abolishment of First Nations ceremonies. https://www.ictinc.ca/the-potlatch-ban-abolishment-of-first-nationsceremonies

Kimmerer Wall, R. (2013). Braiding sweetgrass: Indigenous wisdom, scientific knowledge and the teachings of plants. Milkweed Editions.

Kovach, M. (2009). Indigenous methodologies: Characteristics, conversations, and contexts. University of Toronto Press.

Manuel de cuisine raisonnée. (1919). Manuel de cuisine raisonnée: adapté aux élèves des cours élémentaires de l'École normale classico-ménagère de Saint-Pascal. Imprimerie de l'Action Sociale Ltée.

Martin-Hill, D. (2003). Traditional medicine in contemporary contexts: Protecting and respecting Indigenous knowledge and medicine. National Aboriginal Health Organization (NAHO).

Menzies, C. R., \& Butler, C. (2006). Introduction. In C. R. Menzies (Ed.), Traditional ecological knowledge and natural resource management (pp. 1-20). University of Nebraska Press. 
Merriam, W.B. (1955). The Role of Pemmican in the Canadian Northwest Fur Trade. Yearbook of the Association of Pacific Coast Geographers 17, 34-38. DOI: 10.1353/pcg.1955.0000.

Meyers, R. L. (2011). Best Before: Recipes and Food in Contemporary Aboriginal Art. [Master's thesis, OCAD University]. https://www.collectionscanada.gc.ca/obj/thesescanada/vol2/002/MR82144.PDF Muller, K, M. (2018). Promoting or Protecting Traditional Knowledges? Tensions in the Resurgence of Indigenous Food Practices on Vancouver Island. International Indigenous Policy Journal, 9(4), 1-20; DOI: 10.18584/iipj.2018.9.4.4

Pattinson, N., L. (1923). Canadian cook book. 3d ed. Toronto: Ryerson.Scott, M., \& Sylvestre, G., \& Snyder, L., National Library of Canada (2013). In The Canadian Encyclopedia. https://www.thecanadianencyclopedia.ca/en/article/national-library-of-canada Sherman, S., \& Dooley, B. (2017). The Sioux Chef's Indigenous Kitchen. University of Minnesota Press.

Traill, C. Parr. (1854). The female emigrant's guide, and hints on Canadian housekeeping. Maclear.

University of British Columbia. (2020). Indigenous Publishers, Distributors \& News Media. https://guides.library.ubc.ca/indigenouspublishers

University of British Columbia. (2017). Land Acknowledgements.

https://blogs.ubc.ca/campusenvironments/land-acknowledgments/

University of Regina Regina.(n.d.) Territorial Acknowledgement.

https://www.uregina.ca/indigenization/resources/territoritorialacknowledgement.html

Via Campesina. (2007, February 27). Declaration of Nyéléni

https://nyeleni.org/spip.php?article290

Watts, D., \& Watts, A. (2007). Where people feast : an indigenous people's cookbook. Arsenal Pulp Press.

Waugh, F.W. (1906). Iroquois Foods and Food Preparation. Government Printing Bureau. https://openlibrary.org/books/OL24189548M/Iroquis sic foods and food preparation

Weihs, J. (2019). A tribute to Brian Deer. Technicalities, 39(3), 11-12. https://xwi7xwa-library10nov2016.sites.olt.ubc.ca/files/2019/10/A-Tribute-to-Brian-Deer-by-Jean-Weihs$\underline{\text { Technicalities.pdf }}$ 
Wolfman, D., Finn, M. (2013). Cooking with the Wolfman: Indigenous Fusion. Douglas and McIntyre Ltd.

World Intellectual Property Organization. (2017). Documenting Traditional Knowledge - A Toolkit. https://www.wipo.int/publications/en/details.jsp?id=4235

Younging, G. (2018). Elements of Indigenous Style : A Guide for Writing By and About Indigenous Peoples. Brush Education.

Xwi7xwa Library. (n.d.). Indigenous Knowledge Organization. https://xwi7xwa.library.ubc.ca/collections/indigenous-knowledge-organization/ 